\title{
RUSSIA, THE EU, AND CHINA: FOREIGN POLICY INITIATIVES IN CENTRAL, EASTERN AND SOUTH-EASTERN EUROPE (CESEE)
}

\author{
Olga Shishkina ${ }^{1}$
}

Abstract: In the late 20th century the countries of Central, Eastern and Southeastern Europe (CESEE) faced a deep crisis, which had economic, political, and ideological aspects. The crisis of socialist ideas, the dissolution of the Eastern bloc structures, and the breakup of the Soviet Union have changed the whole European system of international relations.

In the last decade of the 20th century and the first decade of the new century, the CESEE countries were busy reforming. The search for new, more effective ways of political and economic development under the conditions of a single option resulted in the adoption of liberal democracy and the market economy as development models. This predetermined the pro-western foreign policy priorities of the CESEE states. By the early 2000s, part of them joined NATO and the EU. Other states continued to carry out reforms in close coordination with these organizations.

Russia managed to 'come back' to CESEE only in the mid-2000s. By that time, it had redefined its foreign policy interests, which had been largely influenced by the Balkan crisis and NATO enlargement, and had been on the way to complete the economic recovery.

The early 2010s were marked by the emergence of China as another major international actor in CESEE.

Research question: what are the consequences of China's emergence in the eastern part of Europe for the European system of international relations, which already includes the EU and Russia as major players?

\footnotetext{
${ }^{1}$ Associate Professor, in political science (kandidat politicheskikh nauk). Department of International Relations and Foreign Policy of Russia, MGIMO-University at the MFA of Russia.
} 
Hypothesis: a growing competition between the EU and China in CESEE is highly likely. Competition between the EU and Russia will continue, mostly because of the diverging values and approaches to the desired setup of international relations. Russia may avoid competition with China due to the specific features of its foreign policy in the region. The CESEE states can win from the presence of the three actors.

The following issues will be covered:

Which states Russia, the EU and China regard as CESEE;

Features of Russian, EU and Chinese foreign policies in CESEE (their interests, available foreign policy resources, and practices of foreign policy implementation);

The new geopolitical situation in CESEE, created by the presence of the three major foreign policy actors.

The research will be based on the analysis of Russian, EU (enlargement and Eastern Partnership) and Chinese ("Belt and Road Initiative", "17+1") foreign policy initiatives in CESEE.

Proceeding from these sources, the author will conclude on:

The specific situation in CESEE, where three players are interested in intensifying their relations with regional states;

Common and divergent features of Russian, EU and Chinese foreign policies;

The importance of the CESEE states for Russia, the EU and China.

For many years, the countries of Central, Eastern and Southeastern Europe (CESEE) have been at the centre of interest of the leading powers of the world. Their location - close to the developed countries of Western Europe, Russia, and the Middle East - has been the key to their importance for the world. During the Cold war, attention to the region was driven mostly by strategic security issues. After the dissolution of the Socialist bloc, it was regional security and economic matters that made the centres of power keep their eyes on it.

Apart from geographic adjacency, the CESEE countries do not have much in common. What can be named as a recent common historic ground is the choice of further development strategy they had to make after the end of the Cold war and the wish to reach the level of socioeconomic development performed by Western Europe. The reforms of the early 1990s marked a symbolic breakaway from the decades of socialist development. However, both starting positions for transformations and their results varied. More than 15 years after joining 
the EU, the average GDP per capita indicators in the "new" EU member states are well below that of Western Europe.

Differences in terms of political, economic, and social development have made it clear that one needs a more differentiated approach to elaborate an appropriate foreign policy towards these states. At the very least, three groups can be distinguished in the area. The first one includes those that managed to finalize the pro-western reforms in the 1990s and joined the EU and NATO. As their full members, the states of this group carry out national policies in line with the strategic approaches of these organizations. The other two groups include the post-Soviet and Balkan states. Unlike the Central European countries, these states had a vast intraregional agenda that was holding them back in their economic development. Also, in the early 1990s, there was no unanimous wish to join Western European structures and no clear invitation from the EU and NATO to join. For over 30 years, the post-Soviet and Balkan states have been less successful in carrying out domestic reforms and still strive to apply a tested and working model. External resources are needed to improve the economic situation and the well-being of people.

In the new world, after the financial and economic crisis of 2008-2011, there was a wider choice of external resources and foreign initiatives offered not only by the EU and NATO. The changed external conditions, dissatisfaction with the economic situation, and, for some non-EU states in CESEE, the traditions of multilateral foreign policies made them eager to see whether there are possible partners not only to the west but also to the east of their borders. The EU vector remains very strong and, practically, unchallenged in their foreign policies, but it is supplemented by a thorough consideration of what is offered by other players, like China and Russia. Unable and unwilling to stick to just one foreign policy direction, they have been trying to combine the opportunities that the external actors were offering. For that reason, their foreign policies are often described as multipolar.

Until the end of the first decade of the 2000s, the EU, the US and Russia were among the 'non-regional' international actors visibly present in CESEE. For the EU, which has been on the rise since its establishment in the early 1990s, these countries became the main area for the implementation of regional, enlargement, and common foreign and security policies. With the backup offered by the US and NATO in means of ideological, economic and military partnership, the EU was effective in 
establishing permanent frameworks of relations with the countries of the region. For some of them, close ties with the EU resulted in EU membership.

For Russia, a proactive foreign policy was an internationally visible sign of its economic recovery. Its reappearance in CESEE in the mid-2000s was characterized by the attempts to establish a new type of economic relations with its former socialist partners. Active policy in the region was important to ensure that the system of international relations continues to work based on international law principles.

In the second decade of the 21st century, China became one more foreign policy actor, which was highly interested in the CESEE states. For China, the CESEE states became important as the key link between China and the leading European states. Once again in history, the strategic geographic location made these states important for a number of external actors.

The US seemed to be the first to raise the alarm about the growing international presence of China. It was seen as jeopardizing the US influence and "challenging the American power".2 The National Security Strategy named China (along with Russia) "revisionist powers" and accused them of "shaping a world antithetical to US values and interests". According to the US 2017 assessments, China was "reasserting its influence regionally and globally". ${ }^{4}$ To counter such tendencies seen as negative in the US, it started to oppose Chinese international initiatives and took a number of protectionist measures, which turned into a trade war between the two countries.

Unlike the US, the EU at first was less alarmist in its assessments of Chinese foreign policy. In the second decade of the 2000s, Brussels had a hard time overcoming the consequences of the world financial and economic crisis and was facing a number of other regional challenges. One was the 2014-2016 migration crisis when the EU was flooded with refugees, mostly from the Middle East and Northern Africa. Still not fully recovered from the economic and debt crisis, the EU faced the

\footnotetext{
${ }^{2}$ The US National Security Strategy, 2017. P.2.

3 The US National Security Strategy, 2017. P. 25.

${ }^{4}$ The US National Security Strategy, 2017. P. 27.
} 
deterioration of domestic security, which accompanied the migration crisis. Another regional challenge came from a neighbouring Ukraine. The international consequences of the Ukrainian crisis, which started in 2014, led to the disruption of normal and regular political relations with Russia and the fall of bilateral trade by over $40 \%$. Under these circumstances, the EU was reluctant to follow the foreign policy of its closest ally and partner in starting both trade and geopolitical competition with its second-largest trade partner, China. However, Chinese activity in CESEE and its growing economic presence in the "old" EU member states, like Greece and Germany, had triggered the EU response. With some reservations, "the West" showed its common approach to the international challenges coming from Asia.

Thus, complicated relations between the US, the EU, Russia and China in the 2010s were projected to CESEE. The new competitive and multilateral structure of international relations was responsible for very certain assessments and strategies of the major foreign policy actors in CESEE. On this playground, regarded as a sphere of western interests, the US felt necessary to compete with China and prevent it from challenging the US international leadership, while the EU expressed its intention to preserve the strategic partnership with the US and keep its grip on CESEE. Chinese activity in the region is seen in the West as part of a global master plan to challenge the weakened western-oriented world order and set off the competition. In this respect, Russia, which had problematic relations with the US and the EU since the beginning of the Ukrainian crisis, and did not show any renewed activity in CESEE that could bring about more tensions and seemed here a minor irritant for the West. Nevertheless, here it was regarded as a Chinese partner in creating a network of alternative global governance and financial institutions.

\section{EU foreign policy initiatives}

The European Union can only partly be considered an external actor for CESEE. The most proactive and high-performance period of its foreign policy here fell in the 1990s and early 2000s, in the run-up to its largest eastern enlargement. In 2004 and 2007, a large part of these states bordering the EU became the EU members. In 2003, at the Thessaloniki Summit, the Western Balkans were promised to become the EU members. 
The same year saw the start of the European Neighbourhood Policy. That was the time when the EU, as a pole of attraction was at its high, and other major foreign policy actors considered in this paper, like Russia and China, were not offering any alternative initiatives that could be presumably beneficial for CESEE.

From 2007 on, the EU distinguishes between new member states, EU candidates, potential candidates, and neighbourhood partners. By the early 2010s, the EU organized its foreign policy towards the rest of the non-EU CESEE states via Enlargement and Neighbourhood Policies, which have a lot in common except for the EU membership result. However, noteworthy is that candidates, potential candidates and partners in the neighbourhood also include states outside CESEE (Turkey, Armenia, Azerbaijan, Georgia). To be more precise in addressing the states of the region, the EU most frequently uses a geographic term the "Western Balkans", which has been repeatedly named as the next in line of states to join the EU.

Under the conditions of competitiveness with China in the second decade of the 2000s, the EU continues to carry out enlargement policy in the Western Balkans. According to the EU Global Strategy, the EU is interested in the Western Balkans (and Turkey) as necessary partners to tackle 'the challenges of migration, energy security, terrorism, and organized crime.5 The 'strategic challenge' for the enlargement agenda is to promote 'political reform, the rule of law, economic convergence and good neighbourly relations in the Western Balkans' (and Turkey). Therefore, in its policies towards the region, the EU is guided by the interests of its own security and economic development. Not least important is the ability to attract and transform the states bordering the $\mathrm{EU}$, seen as a proof of its international soft power influence. The challenges identified by the EU are to be fought by means of promoting "common values", strengthening the capabilities of states, good governance, and tighter cooperation with the EU. Such priorities are expected to bring peace and prosperity to the region.

The EU 'domestic' difficulties - like debt crises in a number of member states, Brexit, migration and terrorism have affected the EU Western

\footnotetext{
${ }^{5}$ Shared Vision, Common Action: A Stronger Europe. A Global Strategy for the European Union's Foreign And Security Policy. June 2016, p. 24.
} 
Balkans and neighbourhood policies. The concept of resilience has become central to both. The term is positioned as a unique EU foreign policy instrument meant to give the answers to practically any challenges. However, the word implies that the responsibility for fighting the threats and challenges is transferred from the EU to the partner states. They are supposed to become 'resilient' with the support of the EU, which 'enjoys a unique influence' in the Western Balkans and is seen as a development model in the neighbourhood. The 2018 EU Commission Strategy ${ }^{6}$ renewed the membership perspective. However, it called on the states to pay more attention, not only to the traditional reform process but to the irregular migration issues.

Therefore, the EU policy in the region is fully in line with its foreign policy practices. Common values, trade, and integration helped Europe to overcome post-war difficulties. Enlargement strategy with the ideas of "common values", good governance and EU law adoption is based on the experience of bringing Central European states into the EU. The attractiveness served as an additional stimulus for reform when it was needed. It opened new markets to the producers of goods from the EU member states. It demonstrated the superiority of the Western European market economy model and symbolized the increase of EU influence.

The EU applies foreign policy resources at its disposal and trusts the methods that have been checked. However, a number of trends affect existing resources negatively. The economic resources - trade and investment - were hit by the financial and economic crisis. Brexit and the coronavirus downturn may be responsible for the further shortage of available trade and financial resources. The conditionality principle, which proved its effectiveness in stimulating change, continues to serve the EU foreign policy. However, it only works when the EU is attractive to its partners, and the countries believe that the EU-sealed domestic reforms will bring positive change. In this respect, migration, Brexit and the coronavirus response work against the EU and affects both its finances and attractiveness.

Moreover, since 2014, there is also an example of a failed implementation of the EU-recommended reforms reducing the EU's

\footnotetext{
${ }^{6} \mathrm{~A}$ credible enlargement perspective for and enhanced EU engagement with the Western Balkans, Strasbourg, 6.2.2018, COM (2018) 65 final.
} 
appeal. Ukraine did not succeed despite the huge financial support in the last 6 years after the coup of 2014. So far, the pro-EU information resources have covered these negative sides, but the EU's turn to the "resilience" principle can be seen as a sign that it seeks some "safety measures" that would free them of responsibility in case the reforms fail.

\section{Chinese foreign policy initiatives}

China revitalized its foreign policy with the election of a new leader, $\mathrm{Xi}$ Jinping, who took steps to ensure China's global presence. That was a serious deviation from the foreign policy principles formulated by Deng Xiaoping and reiterated by his successors. The principles provided for "hiding the capacities and biding the time" as well as "maintaining a low profile and never claiming leadership". However, such "staying in the shadow" of the world politics now contradicted the economic and political weight gained by China in 20 years, which became especially evident during the global 2008-2011 financial and economic crisis.

Xi Jinping initiated China's more targeted and visible international participation. Its foreign policy was aimed at reforming the global governance system, setting up globalization that would be "more inclusive and mutually beneficial", and "closer multilateral and multilevel cooperation promoting common development". Therefore, China's interests are primarily of political and economic character, i.e., strengthening its role in the international arena and the world trade.

To achieve these interests China started by being proactive on multilateral forums. In 2012-2014, it was BRICS that presented some of the China-proposed foreign policy initiatives. In 2014 the forum gave way to the establishment of a New Development Bank with an initial authorized capital of US $\$ 100$ and US $\$ 100$ billion BRICS Pool of Conventional Currency Reserves (with the largest share offered by China, US $\$ 41$ billion). From the very beginning, both financial structures were aimed at supporting infrastructure and sustainable development projects.

\footnotetext{
${ }^{7}$ Wang Yi, State Councilor and Minister of Foreign Affairs, Speech at the inauguration ceremony of the Xi Jinping Thought on Diplomacy Studies Centre / July 20, 2020. https://www.fmprc.gov.cn/mfa_eng/zxxx_662805/t1799305.shtml
} 
Later, China kept the same focus on infrastructural networks when it turned to presenting initiatives on its own.

The global outreach of China's foreign policy was responsible for its interest in Central and Eastern Europe. Its initiatives in the region include the "17+1" (initially, the "16+1") and the Belt and Road Initiative (BRI). The BRI came into being in 2013 as an umbrella initiative for the two projects - the Silk Road Economic Belt and the 21st Century Maritime Silk Road. The BRI has a global set of countries it addresses (in Asia, Eurasia, Europe, and Africa), and proceeds from a set of priorities which include policy coordination, infrastructure connectivity, unimpeded trade, financial integration, and connecting people. ${ }^{8}$ The huge geographic scope made infrastructure projects key to the implementation of this initiative. Two of the proposed routes have Europe as their endpoints - the New Eurasian Landbridge Economic Corridor and the China - Central Asia Western Asia Economic Corridor. The BRI-involved countries in CESEE are Ukraine, Belarus, Moldova, Latvia, Lithuania, Estonia, and Poland. Thus, the list comprises three post-Soviet Eastern European states, three Baltic post-Soviet EU member states, and just one Central European country, located on the BRI routes.

Although "17+1" was established before the BRI, it supplements the Belt and Road. Interestingly, the Chinese offer makes no significant distinctions between the EU members and the non-members, putting the stress on the common interest, which unites them - to renew the outdated infrastructure and to increase bilateral trade. Hence, among the participants initially were $11 \mathrm{EU}$ members, 5 Balkan non-EU states. Greece was the last one to join the "17+1" in March 2019. The implementation of the initiative, however, added another issue to China's strategic dialogue with the EU. Like the BRI, the "17+1" contains humanitarian cooperation aspects, which means increased intercultural links, student and academic exchanges, and the Chinese language courses. ${ }^{9}$ Since their inception, the activities were supported by a US $\$ 10$ billion credit line by Chinese financial institutions.

\footnotetext{
${ }^{8}$ Belt and Road Initiative // https://www.beltroad-initiative.com/belt-and-road/

${ }^{9}$ China's Twelve Measures for Promoting Friendly Cooperation with Central and Eastern European Countries, 26.01.2015. http://www.china-ceec.org/eng/zdogjhz_1/ t1410595.htm
} 
China's foreign policy in its post-2012 version is aiming to apply the financial resources that China can now distribute abroad. The projects in CESEE are primarily economic, although, to some extent, they serve the interest of China's new global positioning. All projects are well supported by the Chinese state and China-based international financial institutions - the Asian Infrastructure Investment Bank (AIIB), The Export and Import Bank of China, the National Development Bank, the Industrial and Commercial Bank of China, the Construction Bank of China, etc. In CESEE, like elsewhere, it proceeds from the principles of "common good" generally meaning "common economic good" and economic prosperity of the people and "the progress of humanity". ${ }^{10}$ Unlike the EU, it does not seek to spread its values or, in the Chinese case, "socialism with Chinese characteristics", 11 but is proud of its experience of effectively tackling the economic and financial crises and is ready to share the experience of longlasting sustainable economic growth. ${ }^{12}$ Infrastructure as a priority for both CESEE projects demonstrates that China's interest is to have a smooth transport corridor and an entrance to the EU internal market.

\section{Russian foreign policy in CESEE}

In Russia, the region to the west of its borders and up to Germany and Austria in the west is more often described as "Central and Eastern

\footnotetext{
${ }^{10}$ Wang Yi, State Councilor and Minister of Foreign Affairs, Speech at the inauguration ceremony of the Xi Jinping Thought on Diplomacy Studies Centre / July 20, 2020. https://www.fmprc.gov.cn/mfa_eng/zxxx_662805/t1799305.shtml

${ }^{11}$ Wang Yi, State Councilor and Minister of Foreign Affairs, Speech at the inauguration ceremony of the Xi Jinping Thought on Diplomacy Studies Centre / July 20, 2020. https://www.fmprc.gov.cn/mfa_eng/zxxx_662805/t1799305.shtml,

Wei Liu Combining Marxism and China's practices for the development of a socialist political economy with Chinese characteristics // China Political Economy Vol. 1 No. 1, 2018 pp. 30-44.

${ }^{12}$ Wang Yi, State Councilor and Minister of Foreign Affairs of The People's Republic of China, Speech At the French Institute of International Relations, Paris, 30 August 2020. "Upholding the Trend of Peace and Development of Our World with Unity, Cooperation, Openness and Inclusiveness". 31.08.2020. https://www.fmprc.gov.cn/ mfa_eng/wjb_663304/zzjg_663340/xos_664404/xwlb_664406/t1810696.shtml
} 
Europe", "Eastern Europe" (both terms used for Poland, Czech Republic, Slovakia, and Hungary), "Southeastern Europe" ("Balkan states") and the "post-Soviet states" and the "Baltic states".13 However, the term "CESEE" can still be found in some papers as a tribute to the Soviet designation of a region. With regard to the changes that these countries have gone through after the end of the Cold war and the differences between them, geographic and regional names are also in circulation. In most cases, except for the Baltic, the post-Soviet states, which are not part of the EU, are not meant among CESEE states.

In the 1990s, Russia was out of CESEE. With the dissolution of the Soviet Union, there was no understanding of what Russian foreign policy should look like and what foreign policy interests should lay at its core. Furthermore, the country fell short of resources to conduct a proactive policy abroad. In the foreign policy documents, the states of CESEE were excluded from the foreign policy priorities, even though they were still close to the Russian borders. Russian foreign policy was aimed at building up relations with the US and western European countries, which could secure Russia's international recognition and its "inclusion" into the developed western "world". Metaphorically, it looked like Russia was communicating with the EU and with western European states "over the heads" of the CESEE states.

At a political level, there were a number of issues, hindering the establishment of active and friendly relations with the states of the region. On the one hand, ideologically, Russia was no longer posing a development model. On the other, the pro-western governments, which came to power after the communist governments were overthrown in 1989, turned their full attention to the west. Also, with some countries (Poland, Hungary, Czech Republic, the Baltic states), there were some historical issues that were highly important for the political forces in power and made Russia an unwanted partner. For the Balkan states, such ideological and historic issues in relations with Russia were not the case, but this group was entangled in intra-regional ethnic and confessional conflicts. Under these conditions, Russia could only offer its mediating services and not a fullfledged cooperation initiative.

\footnotetext{
${ }^{13}$ Центральная и Юго-Восточная Европа. Конец XX - начало XXI вв. Аспекты общественно-политического развития. Историко-политологический справочник. М.; СПб.: Нестор-История, 2015. 480 с. (с. 8)
} 
Russia's comeback to the international arena with a proactive foreign policy took place only after it had managed to overcome the economic downturn of the 1990s. In 2006 the first signs of this new policy became evident. A new understanding of foreign policy interests came to a couple of years earlier. Interestingly, it was the events in the Balkans that have led to a profound transformation of Russian foreign policy. The 1999 NATO aggression against Yugoslavia was the moment of clarity when Russia came to understand that its interests abroad do not coincide with the interests of western states. NATO eastward expansion, which followed, strengthened Russia's new perception of its role in the world.

The current Foreign policy concept of Russia, which was adopted in 2016, does not mention any of the CESEE states or this region as a whole. This is a change from the previous Russian Foreign policy concept of 2013. The 2013 document contained a passage on the Balkan region in SouthEast Europe, which had an important strategic location and was a key infrastructure and transit hub for Russian oil and gas supply to Europe. ${ }^{14}$

In the 2016 Concept, Russian policy towards the CESEE states is included in a broader abstract dealing with Russia's policy in fostering economic integration in Eurasia and possible interlinkages and harmonization between Eurasian, European, and Asian integration. ${ }^{15}$ Also, some of the passages dealing with the transit of goods and resources, including energy resources, can be applied to the CESEE states like the ones lying on the transit routes and being responsible for a secure supply of goods.

Despite the vague official description of policies towards CESEE and lack of multilateral regional initiatives, some of these is carried out by Russian state companies. Thus, Gazprom, Rosatom and Russian Railway are among the companies with infrastructure projects in the CESEE and ensure the Russian presence there. The Turkish Stream so far has been the biggest project with most CESEE countries involved and interested in gas supply. Some of the projects include people-to-people contacts meant to support intercultural links. ${ }^{16}$

\footnotetext{
${ }^{14}$ Foreign policy concept of Russia, 12.02.2013.

${ }^{15}$ Foreign policy concept of Russia, 30.11.2016.

${ }^{16}$ See: International projects of the Russian Railway. https://rzdint.ru/activity/project.php?page=RS
} 
Like in cases of foreign policies of the EU and China, Russian foreign policy proceeds from the interests it has in the region and from the foreign policy resources at its disposal. It checks whether it is possible to strengthen Eurasian and European integration linkages and to improve regional transit capabilities. Also, it is working on the bilateral level to support cultural and humanitarian cooperation, keep links between Slavic peoples, preserve religious and historic ties, and more specifically, the common perception of the Second World War history. Like China, Russia promotes the idea of cooperation and development for the common economic good. Lack of multilateral foreign policy initiatives with sets of cooperation offers can be explained by the low importance of CESEE as a region for the build-up of the Russian international role. In the absence of financial resources and trade volumes compared to that of the EU or China, Russia offers multilaterally specific infrastructure projects, which are, nevertheless, important due to the importance of energy resources and infrastructure in general.

\section{***}

Since the beginning of the 2010s, there have been a number of initiatives in CESEE by several global actors. The EU, China and Russia became aware of each other's presence and, in the overall context of the structure of international relations, started to regard each other as competitors. Meanwhile, a closer look at the policies of the three actors demonstrates that some differences can prevent the situation from turning into the race and a "zero-sum game".

First, The EU is the only actor vitally interested in preserving its influence in the region. It is also the actor that has already disbursed most of the financial and consultative resources.

Second, only China and the EU have comparable trade and financial resources to compete with each other.

Third, the interests of the three actors in the region vary. For the EU, essential are the interests of security (including "soft security" issues like irregular migration, organized crime), the access to the markets of its adjacent states, the demonstration of its ability to facilitate political and economic reform in other countries, and to spread "European values". In 
the EU case, infrastructure projects are serving the aim of better trade and a more attractive EU image.

For China, it is important to create infrastructural conditions for growing trade volumes and to ensure access to the EU internal market. The CESEE states are only a small part of the global BRI initiative and cannot ensure the success of the whole project. Security issues are not among the top priorities.

For Russia, policy towards CESEE is important to create favourable conditions for its energy and goods transportation to the EU markets. Also, this is the only region in the world with Slavic and, partly, the Christian Orthodox population with which it still seeks to keep traditional ties. Unlike the EU and China, Russia lacks full-fledged multilateral initiatives for CESEE. Its foreign policy focus is on the post-Soviet states, which, in the Russian view, belong to the post-Soviet region, although they are geographically in Eastern Europe.

Finally, available foreign policy instruments demonstrate that competition is possible only between the EU and China. Russia can get involved in the competition not because of its policy in the region, but because of the ongoing shift in international relations and its positions on other key issues of international relations. 